\title{
Literature, Ontology, and Implex in Merleau-Ponty: Writing and Finding the Concrete Limit of Phenomena
}

\author{
Rajiv Kaushik
}

\author{
Department of Philosophy, Brock University, St. Catharines, ON L2R 3A1, Canada; rkaushik@brocku.ca
}

\begin{abstract}
This paper examines the ambiguous relationship between the literary uses of language in Merleau-Ponty's own work and his ontology. It is argued that Merleau-Ponty's critique of phenomenology - that is, his critique of an already critical philosophy-leads him to say that the limits of phenomena are inside the entire structure of the phenomena. They are, in other words, promiscuous or dehiscent and therefore are not limits that can themselves be given. Merleau-Ponty would say that such limits are silent or mute within meaning. This will have repercussions for the very method of phenomenology. It can no longer be a descriptive method, concerned with the givenness of the phenomena, but needs to be matrixed with an expressive method that shows up the impossibility of such a return. This expressive method has to do with what he calls the "implex" - the very bodily limit of the inside and the outside that cannot be thought as one or the other, or even their synthesis. In other words, Merleau-Ponty's phenomenology invites us towards a concrete bodily limit that is, at the same time, a limit to philosophy. In effect, one cannot think of Merleau-Ponty's ontology of the flesh apart from language, because this ontology, its very concrete crystallization, requires expression and not just description.
\end{abstract}

Keywords: literary usages of language; metaphor; expression; body; voice; implex; Paul Valéry; ontology

check for updates

Citation: Kaushik, Rajiv. 2021. Literature, Ontology, and Implex in Merleau-Ponty: Writing and Finding the Concrete Limit of Phenomena. Humanities 10: 118. https://doi.org/ 10.3390/h10040118

Received: 12 October 2021

Accepted: 5 November 2021

Published: 10 November 2021

Publisher's Note: MDPI stays neutral with regard to jurisdictional claims in published maps and institutional affiliations.

\begin{abstract}
Keywords. literary usages of language, metaphor; expression; body; voice; implex; Paul Valéry; ontology
\end{abstract}
Themes such as "shadows" and "ambiguity" run throughout Merleau-Ponty's writings, part of his overall critique of intentional consciousness and the thesis that intuition grasps this consciousness in its ideality and with absolute clarity. In the "Intuition and Interrogation" chapter of The Visible and the Invisible, Merleau-Ponty (1968, pp. 118-19) writes the following remarkable passage:

If there is an ideality, a thought that has a future in me, that even breaks through my space of consciousness and has a future with the others, and finally, having become a writing, has a future in every possible reader, this can be only that thought that leaves me with my hunger and leaves them with their hunger, that betokens a generalized buckling of my landscape and opens it to the universal, precisely because it is rather an unthought. Ideas that are too much possessed are no longer ideas; I no longer think anything when I speak of them, as if it were essential to the essence that it be for tomorrow, as if it were only a taking thread in the fabric of the words. A discussion is not an exchange of a confrontation of ideas, as if each formed his own, showed them to the others, looked at theirs and returned to correct them with his own ... Someone speaks and immediately the others are now but certain divergencies by relation to his words, and he himself specifies his divergencies in relation to them. Whether he speaks up or hardly whispers, each one speaks with all that he is, with his "ideas", but also with his obsessions, his secret history which the others suddenly lay bare by formulating them as ideas. Life becomes ideas and the ideas return to life, each is caught up in the vortex in which he first committed only measured stakes, each is led on by what he said and the response he received, led on by his own thought of which he is no longer the sole thinker. 
Read this passage, and you will notice a critique of the singular, ideating, reflexive consciousness: So long as it is thinking, consciousness is not present to itself but possessed with an unthought that rushes up through it. Thought is not only silently monological, in other words, but also silently opens up to dialogue and discourse. It bears a still more profound silence of language than the silence I alone hear in my head and think of as "my voice" - a silence in speech opened out into the world. This is Merleau-Ponty's philosophy of écart, in which a most profound silence always already surges up through consciousness and undoes the primacy of its self-identity, a consciousness internally constellated by difference. How could phenomenology, a decidedly reflexive philosophy, manage such a reversal? Listen to this passage, and you will hear Merleau-Ponty's critique, a certain rhythm and cadencing of the sentences and their literary, expressionistic character. That is, you will hear the critique of the singular, ideating, reflexive consciousness and its monological attempt at total clarity. Merleau-Ponty writes in such a way that is not only phenomenologically descriptive but so that language itself slips out from underneath monologue and ideation and regains a certain traction in speech and discourse. If we commit to the voice of Merleau-Ponty's writing, in other words, we are invited to commit to a philosophy that rides the adventure of discourse itself and no predetermined "end" or "direction".

In this way, I think, Merleau-Ponty anticipates and even puts on display a project of Derrida's. In White Mythologies, for example, Derrida notes that metaphysical language surreptitiously raises its negative concepts (e.g., ab-solute, in-finite, non-Being, etc.) to the level of reality, while relegating metaphors to fiction and unreality. The implication is that philosophical texts maneuver an alteration in the language and possess a "surplus value" unexplored in the text itself. ${ }^{1}$ In a similar vein, in "Qual Quelle", commenting on Paul Valéry, Derrida notes that philosophy is regulated by the law of pure cognition and is the desire to hear oneself speak in monologues. To break from this tendency, it would have to be written and would especially need poetry. Of course, Merleau-Ponty and Derrida have often been compared. In particular, Merleau-Ponty's late ontology can be seen as a close cousin to Derrida's Voice and Phenomenon, which, through a certain critique of phenomenology and Husserl's Logical Investigations in particular, begins his deconstructionistic project. However, there are vital ways in which they diverge from one another: They do not have the same critique of intentional consciousness and intuition of it; they thus do not have the same conception of a non-monological philosophy; and, consequently, they do not conceive literary language as the internal limit of philosophical language in the same way. In fact, I will argue Merleau-Ponty's critique of intentionality concerns its internal constellation, and therefore also a voice that internally constellates reflexion and the literary within the philosophic.

\section{Merleau-Ponty and Derrida: Initial Considerations}

An issue in Voice and Phenomenon is the problem of givenness and intentional consciousness, its structure of noesis and noema (its structure of sense and meaning), and thus signification. Derrida wants to show that, right from the start of his Logical Investigations, there is something unwarranted-and so uncritical-in Husserl's decision to consider reflection on the sign only in terms of a logic that can be brought to its pure expression (Ausdruck) (Derrida 2010, p. 46). The result is that Husserl's phenomenology omits a different project, which concerns a logic of signification that cannot be expressed but only indicated (Anzeichen). This latter project involves an investigation of the self-absence that Derrida equates with the body and its voice. It is only on the basis of this uncritical exclusion, Derrida argues, that Husserlian phenomenology thinks of consciousness as complete self-presence, capable of immediately grasping what is essential to its own being.

Just when Derrida points out this basic distinction between expression (Ausdruck) and indication (Anzeichen), he says the latter is deprived of "signification" (Bedeutung or Sinn) and is a "bedeutunglos" or "sinnlos". "Nevertheless", he writes, "it is not a sign without signification, a signifier without a signified" (Derrida 2010, p. 15). This is a quick reversal: 
Indication is a mode of signification absent of signification; and precisely this absence presents itself as what is absent. If this is the distinction Derrida's argument in Voice and Phenomenon rests on, the text places the intentionality of non-signification, that is, the intentionality of the body and voice, at its core. Actually, despite what Derrida says, this very structure of intentionality is at least obliquely anticipated by Husserl in Ideas I. There, Husserl proposes Bedeutung and Sinn differently: The former concerns meaning at the conceptual, logical level; the latter concerns the sense of meaning in a much broader sense. The former applies to acts of expressing and the latter to all acts. The "intentional object" is meaning in the sense of "reference" whereas noema is meaning in the "sense of sense" and is distinguished from reference. Thus, what Husserl calls a "noematic nucleus" is the Sinn of the noetic act of consciousness but it does not have a conceptual or logical meaning and does not need a reference. One can go further with this: In $\$ 69$ c, for example, in what may be a rare reference to Freud, Husserl speaks of the "zone of obscure apprehension" of presentations, which "due to psychological hindrances", cannot cross the threshold of clear consciousness. The connection between Freud and Husserl is Brentano, who proposes that some intentionalities have such liminal intensity that, in them, what is given remains unnoticed. Once we admit the fact of un-present presentations, un-given givens, or unconscious consciousness, they are no longer marginal to phenomenology, and subsequent phenomenologies, as in Heidegger or Ricoeur, need to account for them.

Even more concerning is that Derrida's argument against Husserl implies an allegiance to the claim that the absent might present itself. This is an allegiance to the Husserlian dictum that the "possible is higher than the actual", and to the importance of the "experiencable". The idea that non-significance must in fact in some way present rests on the idea of intentionality itself. I have argued elsewhere that Merleau-Ponty has a systematic antagonism to the phenomenological reduction and to the entire structure of intentionality and signification. ${ }^{2}$ Inasmuch as he thinks the reduction, as a critical intervention of all naturalistic theses, also sediments and remains uncritical with respect to this latent production, he thinks there always remains something unsedimented in the very intentionality and signification to which it reduces. What he calls "silence", or "mute meaning", is in effect an un-signified that internally constellates intentionality and signification. Merleau-Ponty's thesis, I think, is not that there is an absence that presents itself as absent but a more radical claim and critique of phenomenology: There is in fact a non-significance internal to signification that makes signification possible; this non-significance does not itself signify but is rather threaded throughout the entire axis of relation between the signifier and the signified, equally within both, so that we can think of the former referring to the latter and the latter as what is meant by the former. Since this non-significance is both within the signifier and the signified as well as unaccounted for by them, it is the very thing that Derrida says is an impossibility in Voice and Phenomenon. This impossible limit is however what Merleau-Ponty calls the "symbolic formation" or symbolization-a limit within intentionality and signification, which internally constellates, or is the écart, of them-a silent voice within signification about which we cannot speak.

What is true for Derrida is also true for Merleau-Ponty, then: Philosophy is not only served by a monologue, or by a pure description that retrieves the original intuition of signification. However, since Merleau-Ponty is not concerned with the ruination of intentionality but with what is inside it, his critique of pure description also does not lead to the ruination of phenomenology. It instead forms what Merleau-Ponty calls "indirect ontology"; and this ontology, even more than does Derrida's account of speaking and the voice, draws together existence and writing, the figures of language and the figures of the body. ${ }^{3}$

\section{Is Indirect Ontology an Ontology of Metaphor?}

It is sometimes argued that the "indirect" ontology requires an indirect language as opposed to a direct language; and in particular it requires metaphorical language as opposed to scientific language. The most famous argument about this is found in Renaud Barbaras's 
essay "Métaphore et Ontologie" (Barbaras 2009, p. 281). Here, Barbaras is concerned to transgress the limit imposed on metaphor by Paul Ricoeur, who famously wrote about the "semiological challenge" to Merleau-Ponty's phenomenology. For Ricoeur, metaphor is a break from ontology. He starts with Aristotle's classic definition that metaphor involves bringing disparate terms together so that they suddenly appear "close", and thus it forms a kinship between heterogeneous ideas to make a new sense. This means that metaphor implies a transfer of sense from an everyday, or direct, use of a word or words to a novel, or indirect, purely linguistic use of words. Then, Ricoeur extends this purely linguistic use of words to the level of the sentence and to metaphorical statements. In which case, the transfer of sense from the direct to the indirect bears on language itself and destroys the consistent or lexical meanings of the terms the metaphor employs. There is therefore an "innovation" and totally new use of the imagination that is non-logical and opposite to the coherent use of the imagination in direct language. Actually, Ricoeur points out, the term "figure" (linguistic figure, figure of speech, figure of language, and so on) is already a metaphor we use when we talk about metaphors. It suggests that the new use of imagination in the metaphor has its own purely virtual terrain and shape, distinct from the actual and sensible terrain and shape in which we exist. Moreover, the "figure" is a spatial metaphor that indicates we do not have a real idea what we mean by metaphor in language; so, when we use the metaphor of "figure", this is already the destruction of a logical space, the expression of a notion impossible to express, and therefore the formation of the circumference of a purely linguistic space opposite to a sensible space.

Against this view, Barbaras argues that in Merleau-Ponty's ontology, the écart does not just return being to metaphor but actually makes them synonymous with one another. This is because, inasmuch as being is itself the bringing-together of otherwise disparate terms under one ontology, it allows us to understand how a thing may be "another thing while also not being that other thing", and this "permits us to remove the paradox [of being] in such a way that a being would never be itself except in not fully being itself" (Barbaras 2009, p. 281). Even if I think there is an ontology of metaphor in Merleau-Ponty, I also think the "removal of the paradox of being" is an issue. It undermines the very notion of écart and, where Ricoeur supposes a virtual innovation of the imagination, instead supposes an ontological innovation that bears on the beings that are opposite to it-an ontological creation independent of the visible world and its expression. This is what allows Barbaras to claim that, where scientific or direct discourse veils being, poetry or indirect discourse unveils it. The effect is a complete reversal of Ricoeur: Metaphor does not explode the sensible but rather reduces direct language in order to unveil a sensible world that then, for its part, remains self-identical. Barbaras in The Being of the Phenomenon: "Far from the metaphor bearing on objects already circumscribed, things proceed from a general 'metaphoricity', from a universal participation that they concretize or crystallize in order to be constituted into things. The dimension of sense, at once figurative and figured, is the truth of sense itself" (Barbaras 2004, p. 195).

I disagree that there is a "general metaphoricity" or "universal participation" in one sole dimension, but this does not mean Merleau-Ponty's ontology is antagonistic to metaphor, only to the traditional rhetorical definition of metaphor. There is the possibility that metonym sometimes defines metaphor. There is also the idea that chiasm can be metaphor. Glen Mazis, for example, relies on the chiasm, and what he describes as the bringing together of incompossibles, to define metaphor in Merleau-Ponty (Mazis 2016, pp. 288-89). The chiasm, a term Merleau-Ponty borrows from Paul Valéry, is a rhetorical structure in which two clauses are balanced against one another and then again appear in reverse order (e.g., "the fair is foul, and the foul is fair"), in which case, the two clauses work by counter-positioning. They not only intercross but also balance and reject one another. Emmanuel de Saint Aubert argues that in the "Cartesian Ontology and Ontology Today" lecture Merleau-Ponty decides on the word "metaphor" not to remove an ontological paradox but to stress it: "a philosophical word more appropriate to the paradoxes of our condition ... bearing an 'essence common to the real and imag- 
inary', 'bearing meaning, not as an idea of the intelligence', but meaning as metaphor" (De Saint Aubert 2020, p. 155). That is, a term that highlights the paradox and continual transference between the visible and the invisible or the real and the fictive. This may be related to the surrealist tactic of placing two unanticipated objects alongside one another-a roto-dial phone and a lobster, for example-to announce a dimension of their existence that was not previously there.

Another way to say this, I think, is that metaphor is the configuration of both the visible and the invisible, or the real and the fictive; and, accordingly, direct and indirect language. This requires us to reconceive the movement between the two. Instead of indirect meaning interrupting and reducing the direct meaning, the move from direct meaning to indirect meaning involves an interior dislocation of the former-an unsedimentation of direct meaning from inside of it. Freud in his work on hysteria first calls this very movement a "symbolization". Eugene Gendlin explains it this way: When we bring "flame" and "love" together, the direct meanings of "flame" and "love" are each subverted with indirect meanings and revealed to be "multischematic" (Gendlin 1997, p. 171). This is not just the supplantation of an old meaning with a new meaning. Instead, when old meanings are intercepted with indirect ones, the old meanings are also revealed to have been constellated with multiple and non-obvious meanings. We understand that "flame" and "love" are not just what we say they are. Here is one moment of what Merleau-Ponty means by the "paradox of expression": The indirect meaning does not remove the direct one, but rather the indirect meaning expresses a repression internal to the direct meaning; and this, in turn, means that the indirect meaning itself contains the possibility of old and sedimented meanings. For example, there is always the possibility of a "dead metaphor". Indirect meaning is, in other words, always open to systematization and absorption into direct meaning. The entire language system is neither logical and conceptual nor imaginative and creative but the constellation and lateral movement between them. It is thus possible to say language is a transversal slice of itself. Consider this passage from Merleau-Ponty's Signs (Merleau-Ponty 1964, p. 77):

A language which only sought to reproduce things themselves would exhaust its power to teach in factual statements. On the contrary, a language which gives our perspectives on things and cuts out relief in them opens up a discussion which does not end with the language and itself invites further investigation. What is irreplaceable in the work of art? What makes it far more a voice of spirit, whose analogue is found in all productive philosophic or political thought, than a means to pleasure? The fact that it contains, better than ideas, matrices of ideas-the fact that it provides us with symbols whose meaning we never stop developing.

Merleau-Ponty's thesis here is that language is, by its nature, always indetermined and has an inexhaustible meaning. He does not say this meaning is innovative or that it is veiled by scientific or direct discourse, nor does he say that indirect language reduces direct language and exposes it for what it is. He certainly does not say that indirect language comes from or is merely subverted by direct language, or that indirect language stands in need of clarification by direct language. This is why I have stressed in my own work that Merleau-Ponty, against Ricoeur, takes away the metaphor of the figure. ${ }^{4}$ There is, for Merleau-Ponty, a liminal or medial space between indirect and direct language, and thus also between the shapes and terrain of the virtual linguistic system and the actual shapes and contours of bodies. I say "medial space" for a reason too: Though it is non-objective, there is a nonetheless concrete site where the symbolization-the very movement between direct and indirect language-occurs. Furthermore, the space of this "figure" presumes a symbolization or a symbolic formation; it cannot itself be thought according to direct or indirect language since it is what constellates them.

In other words, what I say directly inevitably contains more than what I mean; and there is something unsaid that always internally constellates what I say. This implies that my use of language is internally delimited. This internal delimitation further means that my use of language is simultaneously also impersonal. Such constellation requires 
that language is the point at which I am individuated ontologically; which is to say, it is not specifically located but dehiscent or promiscuous. For the same reason, however, there can be no philosophy "about" this language, because such a philosophy already reduces its dehiscence to something locatable or denotational. Any philosophy adequate to the personal and ontological situation of language would at the same time also have to be a philosophy that operates a transversal slice of itself and reconceives the situation in which it finds itself. This would not be a critical philosophy of limit-situations in any heretofore sense. It would not be a matter of "going back up to the "conditions of possibility" but rather "an ascent on the spot (ascension sur place)" and is always "as on the first day" (Merleau-Ponty 1968, p. 177). The entire symbolization of language, between direct and indirect meaning, what is said and unsaid, implies a limit in consciousness to which consciousness cannot be directed and which is also not prior to consciousness. Merleau-Ponty would say, following Blanchot, that these limits are between life and death, between the first and last breath, between the first cry and the last. ${ }^{5}$

\section{The Implex, the Voice of No One}

This internally constellated limit is nonetheless concrete rather than abstract and does have a name: The implex (Merleau-Ponty 2013, p. 103). Though there has been very little written about the implex in Merleau-Ponty until recently, Derrida does write explicitly about it in Valéry. He describes it as the pure condition of the "potentiality to act", to break off communication with the exterior and give up the "affirmation of mastery by means of the exercise of style". It is in this respect, at least in Derrida's reading of Valéry, where a "self-presence whose dynamic virtuality", is set against the "contingent, conditional" (Derrida 1982, pp. 295, 303). This is to say that the implex is the point at which contingency is delimited from inside, which puts an end to my contingency; and, as Derrida says writing about the heart in Nancy's work, a limit that cannot be touched where it is instead, "a limit that also becomes its own limit". Fundamentally self-intimate, in other words, the implex is in a sense heterogeneous. It seems like my passivity, but then again it has an activity of its own. That, anyhow, is the lesson Nancy draws from his own heart attack, which he writes about in "The Intruder". It is, as Derrida says, an "effraction of the other", a "syncope", a "gap or dilation without return", which "does not let itself be gathered up or contracted in the relation to self" (Derrida 2005, pp. 281-82).

Valéry himself relates the implex to the optic nerves and to the musculature that is not consciously activated. This is important because, according to Merleau-Ponty, the implex therefore has to do with "the chiasm". In addition to a literary device, a "chiasmus" refers to the intercrossing of the optic nerves on the body of the sphenoid bone so that, in binocular vision, the left and right eye function in equal measure. I cover one eye, and I have one point of view. I cover the other, and I have another point of view. The chiasm not itself a singular standpoint but the possibility of two points of view that ordinarily seem to be one. It shows, in other words, that the body is itself the site of difference and is in fact constellated or matrixed by an internal counter-positioning. Merleau-Ponty writes that, "by a certain dehiscence the body opens up in two". He writes elsewhere that the body is "the advent of difference" and even the "possibility for separation (two eyes, two ears: the possibility for discrimination, for the use of the diacritical)" (Merleau-Ponty 1968, p. 224). It is somewhat of a wonder that Merleau-Ponty did not also refer more often to the eyelid to expand on what he called the "blind spot" (Merleau-Ponty 1968, p. 210): Something of the body that cannot be seen so that there is vision; but which for its part is between the pure activity of seeing and the pure passivity of being seen - an insensible limit that internally constricts and is in the middle of these two extremes so as to prevent them from being absolute.

Derrida's definition of the "absolute" and "self-intimate" limit, to describe the implex as what is insensible in the sensible, needs some revision here. If I say my heart is on my inside, for example, this already does a disservice to the fact that it is not completely mine and something about it is the same as what is external to me. However, as soon as I 
say that it is the same as what is exterior to me, this is also a disservice to its peculiarity and the fact that I, and I alone, am dependent it. To locate the organ one way or another, give it a particular place, or reduce it either to interiority or organic material, is to ignore its non-objective and peculiar space according to which my internal and external are. In short, the implex is what of the body remains elided both by sensation itself and our conceptualizations of it. This insensible limit is not itself locatable but is rather spread or dispersed along the access of the whole of the relation in sensation. That is, rather than heterogeneous, Merleau-Ponty would say it is dehiscent or promiscuous-nowhere in particular because it is in fact everywhere.

It is less a question of intending to put into action the implex than seeing it as a limit between language and existence that nonetheless sets these disparities into their relative places. Here is Merleau-Ponty in an April 1960 Working Note (Merleau-Ponty 1968, p. 246):

The I, really, is nobody, is the anonymous; it must be so, prior to all objectification, denomination, in order to be the Operator, or the one to whom all this occurs. The named I, the I named (Le Je dénommé, dénommé Je), is an object. The primary I, of which this one is the objectification, is the unknown to whom all is given to see or to think, to whom everything appeals, before whom ... there is something. It is therefore negativity-ungraspable in person, of course, since it is nothing. But is this he who thinks, reasons, speaks, argues, suffers, enjoys, etc. Obviously not, since it is nothing-He who thinks, perceives, etc., is this negativity as openness, by the body, to the world-Reflexivity must be understood by the body, by the relation to self of the body, of speech. The speaking-listening duality remains at the heart of the I, its negativity is but the hollow between speaking and hearing, the point where their equivalence is formed-the body-negative or language-negative duality is the subject-the body, language, as alter ego ...

There is an anonymity that is concrete and related to the speaking and listening or hearing situation between two interlocutors. When my interlocutor speaks, for example, strictly speaking I do not hear her but the resonance of her voice inside my ear. What I hear is my own hearing. There is, in other words, an internal discrepancy between hearing and speaking, and the entire interlocutionary situation is shot through with a silence that for its part does not speak but which makes hearing and speaking possible. Merleau-Ponty in the passivity lectures refers to the "unspeaking speech"; and, referring to the implex and Valéry again, he calls this silence "the voice of no one". The "voice of no one" is not a disembodied voice "in the third person". ${ }^{6}$ It gives the impression of being a "third meaning" between interlocutors, as though it was always there, in wait to be discovered, but is in fact the "no one" in the midst of speaking and hearing.

Another articulation of the paradox of expression arises: Speaking and hearing convey something "to be discovered" only in the very event of interlocution. Suppose, for example, I am trying to say out loud an inchoate thought. I may not know what to say, I may not even know that I wanted to say something at all, until I have blurted it out; and suddenly what I have said is what I have been wanting to say all along. The paradox here is a self-censoriousness that has prevented me from saying what I want, or even knowing what I want to say, which turns out to be the very urgency of speaking. A self-ignorance, or repression, becomes the possibility for expression. These are lateral to one another, not hierarchically arranged. If I am not suddenly viewing myself from the third position, it is because the language I usually think is under my own power and perfectly virtual in fact in the world where it is spoken and heard.

In the instant when what I have said now appears to be my statement, though, I take my statement to be virtually my own and this transforms the space of interlocution to be actual and denotable-something "about which" we can both speak. When I say that "an object is behind me", for example, what was previously the unplaceable limit of the implex becomes something locatable and foreign to me. I now alter, too, what was previously displaced about my own existence. I displace the fact that I am concretely, at 
the implex, displaced. This is, I think, one sense in which Merleau-Ponty borrows André Malraux's phrase, "coherent deformation": The coherency and referencability of existence is in fact a deformation of what was previously deformed; they displace displacement itself. In doing so, there is notably something productive: The implex, say, all the musculature of my tongue and larynx, now appears divergent and in fact unrelated to, the very language I now declare as mine.

Merleau-Ponty says that the implex is the "unconscious" and the animal of words, the animal of events. and even the animal of symbolic emblems. It is worth remembering here Hyppolite's formulation of the unconscious, which Merleau-Ponty refers to time and again: "I do not know it; I knew it is all along". The implex is an interdiction to touch it (it says: noli me tangere) and yet, through it, language touches upon it. The implex is, in other words, the untouchable limit of what we touch on in language. It is both a "censor" and "positive", something Merleau-Ponty calls a "positive symbolism". The symbolic is positive because, inasmuch as it produces both the inside and the outside, without it there would only be a parallelism and the meaning of which would not intrude on the other. However, the symbolic is censorious because, to the extent that it produces this duplicity of the inside and the outside, it cannot itself be thought according to their relation and is in this sense their immanental limit. Such a limit is precisely what allows the two meanings to be mutations and intrusive to one another. Freud himself affirms this reading of censorship in his "Revision of the Theory of Dreams" when he says, for example, that it's "inaccurate to think of the "unconscious repressed" versus the "conscious" but rather we should think of a "resistance due to a repression by which the two agencies are separated" (Freud 1992, p. 39). Merleau-Ponty, referring to an "unconventional thought" that Freud opens up but may not himself traverse, argues that the positive symbol introduces a limit into the individual, a limit of me that is not my own, that does not just concern just the etiology of the individual but which nonetheless produces the etiology. The symbolic, in other words, delimits both self-reflection and the things I reflect on. It delimits me from myself as well as from the world. It introduces a limit within me that is not my own.

This is precisely why Merleau-Ponty continues to say that the implex is the "unknown acting and organising dream and life, principle of crystallization (rameau de Salzbourg), not behind us, fully within our field, but pre-objective, like the principle of segregation of "things". ${ }^{7}$ The implex is equally between latent and explicit meaning, ourselves and the world, and even the things of the world. The reason this implex and the symbolic are so intimately inter-connected is thus because, in both, there is no ground or origin but rather a limit that matrixes itself within the very terms of a reflexion that now cannot apprehend it-a constraint within reflexion that cannot be grasped according to the terms of the very reflexion which it initiates, a genuinely brute and carnal principle that effaces itself in those terms and resists them. This anticipates Merleau-Ponty's statement that the flesh has "no name" in the history of philosophy. Of course, the rest of the statement stresses the "elemental" character of the flesh, which I have also tried to relate to Heraclitus's Fragment B45: "The logos of the psyche has such depth that we may never reach its limit, no matter what path we take or how far we travel". What has "no name" in the history of philosophy applies equally to the depths of my own psyche, which has no bottom, and to the texture of things, which has no outer limits. The further out into existence I travel, the more I am confronted with the depths of my own interior existence and the impossibility of knowing it. Which is to say, the psyche is concretely figured. There is thus no indirect language outside existence that deals only with the fictive; and no direct language that accounts only for the real.

\section{Philosophy and Literature}

How might phenomenology go to this figure, to this heart? The implex is neither the subjective interior nor the objective exterior. Yet, in configuring them, it is a still more interior moment of the sensible irreducible to sense-perception and in particular to sensecertainty. This does not mean that the implex is irreducible to "sensation". Just as it belongs 
to a space with "no name", the implex belongs to a sensation with "no name". Here, it is possible to find words touching, to touch on the unconscious, to touch the heart of things. These, too, are aspects of le sentir, and not just metaphors in the traditional rhetorical sense. It might also be worthwhile to wonder here if words have or are themselves "feelings".

Consider the symbolization of metaphor a little further. Where language is direct, it refers to a meaning. However, if this direct language is also constellated with an indirect meaning, then even when language refers to a meaning it is simultaneously unable to elucidate meaning entirely. In this case, language is incapable of circumnavigating itself to speak about what is beyond it. However, this does not then imply that meaning pre-exists language so much as it diminishes the authority of direct meaning. The direct meaning refers to something outside language-an object, say-only in retrospective view of the incapacity of language to exceed its bounds and its incapacity to exceed indirect meaning. This happens, too, in the reverse. I conceive of myself as a subject prior to language only in a retrospective view of language. The entire constellation or matrix between direct and indirect language sediments language's apparent denotational structure. This matrix, Merleau-Ponty thinks, is the "ontogenesis" of language. ${ }^{8}$

Whereas Saussure says very clearly that examination of the language system does not require discussion of its "ontogenesis" (De Saussure 2009, p. 9), Merleau-Ponty would say that language generates both its meaning and its referent and, thus, meaning and the referent only appear in virtue of language. If language is ontogenetic in this way, we cannot say that it is "about something" or that it has a denotational structure. Even indirect meaning is not merely a meaning that presents itself indirectly as an absence. This is the same critique of intentionality with which I began this paper: For Merleau-Ponty, there is an indirect meaning inside signification, a silence or mute meaning inside language. On the basis of this matrix between silence and language, there is another matrix between language and ontogenesis itself-an ontological problem that does not exclude, but rather even generates, the entire structure of intentionality and signification. This is why, in a direct reference to the Lacanian thesis that the unconscious is like a language, which Merleau-Ponty says just a "regional problem", the more ontological issue is that being is itself structured like language (Merleau-Ponty 1968, p. 165). That is, being is dehiscent or promiscuous, threaded throughout all signification; and for this reason we do not find it at any one place: On this side of what is said or on that side of what is heard, on this side of the connotative or on that side of the denotative, on this side of indirect meaning or on that side of direct meaning. The refusal to juxtapose the indirect and direct languages allows Merleau-Ponty to articulate the interior limit to both language and ontology, and that is the implex - the brute and carnal texture of my interior life and exterior world.

The recent publication of Merleau-Ponty's 1954 lecture course at the Collége de France, Sur le problème de la parole, makes clear that Merleau-Ponty was thinking about the contingency of language and ontology-placing their mutual contingencies inside one anotherwithout relying on Heideggerian ontology. For instance, the work with which this lecture is initially concerned is "La notion de verbe", which was written by the French linguist Jean Fourquet in 1950. ${ }^{9}$ Merleau-Ponty's own formulation of the internal contingency of language and ontology produces a question he asks overtly in The Visible and the Invisible: "But then I will have to disclose a non-explicated horizon: that of the language I am using to describe all that-And what co-determines its final meaning" (Merleau-Ponty 1968, p. 230) What language, Merleau-Ponty is asking here, would disclose the fact that language is itself ontogenetic? What language could possibly reveal the ontogenesis of language that no language could ever be about? The answer is: None in particular. Here, it is worth considering the locus classicus on this matter, a working note to The Visible and the Invisible titled "Philosophy and Literature" in which Merleau-Ponty says that being demands creation. He also says that he wants to "make an analysis of literature" that would be an "inscription of Being", and he openly wonders whether in such an analysis phenomenology would become the "supreme art". ${ }^{10}$ 
Importantly, the notion that philosophy may be a supreme art comes to Merleau-Ponty from Étienne Souriau's L'instauration philosophique (Souriau 1939), "instauration" being another way to say "instituting". The supreme art of philosophy would be the exposition of what was previously hidden and impossible to recognize in the instituted value or norm. ${ }^{11}$ This is the sense in which Merleau-Ponty says that ontological creation is "creation in a radical sense: a creation that is at the same time an adequation, the only way to obtain an adequation". It would have to be a phenomenology that conforms whatever is instituting to the norm and turns it into the instituted. At this point, Merleau-Ponty also says, the supreme art "considerably deepens" Souriau's view: Art and philosophy go together on the basis of a certain texture of existence that does not pose the spiritual against the material or the fictive against the real. Merleau-Ponty never says his phenomenology is a supreme art, however. Elsewhere, though, he does explicitly say that Proust is a philosopher-pointedly, not a Platonist, as Sartre claimed-who "enters" or "opens" into things and "make accessible to others exactly that which is silent" (Merleau-Ponty 2019, p. 46). There are other such philosophers for Merleau-Ponty, too, notably Stendhal and Valéry. One way Stendhal and Proust in particular are philosophers might be that their "autobiographical fictions" place in question the author's language as "her own". They place in question what Merleau-Ponty, referring to Valéry, calls the "false illusion" (Merleau-Ponty 2013, pp. 111sq. and 115sq) of authorial intent. If one reads the author without this false illusion, then one is placed in arrest and is unsure who or what she is reading about. This might be called a "true illusion". Language is a true illusion because it is a private, individuated limit that is, at the same time, public and belonging to all users of the language. It thus places into question the relation between description and expression, the issue of whether in description we can retrace our steps to the origin of signification or if in expression we are given the impression that such a return is possible. The supreme art phenomenalizes precisely this matrix. In doing so, it expropriates from ontological absolutes an ontological texture about which there is not one thing to be said, about which nothing specific can be said. It finds itself at the very pulsations of life.

Here, it is possible to ask a question that in another context would seem stupid: Is Merleau-Ponty a philosopher? Does he do a supreme art? In addition to reading him, one also has to listen to Merleau-Ponty, that is, pay attention to the undulations and cadences of his sentences, to get the sense that he is. His essays are incomplete thoughts and oftentimes expressionistic. The last ontology of The Visible and the Invisible is punctuated with working notes that read like philosophical fragments. Its completed parts, like the passage with which I opened up this chapter, are highly poetic. There are also many key phrases borrowed from literary figures in his work: "chiasma" from Valéry, "coherent deformation" from André Malraux, "flesh of the world" from Claude Simon. There are plenty of memorable images and metaphors in Phenomenology of Perception used to construct his phenomenological descriptions, and the entire book ends with a reference to SaintExupery's Pilote de guerre. However, if this supreme art concerns a certain symbolic, rather than foundational, texture of things, we must make one admission about it: It is contingent. None of it was necessary, all of it could have been something else, and it all could have been written or said in some other way. There is no reason for this philosophy to be.

Funding: This research received no external funding.

Conflicts of Interest: The authors declare no conflict of interest.

\section{Notes}

Derrida asks in White Mythologies: “Is there metaphor in the text of philosophy, and if so, how?" In the text of philosophy, it is assumed that language is the proper elucidation of real events. But this is an untenable assumption. If words truly pointed to such events, they would not themselves be elucidatory. The text is instead, according to Derrida, surreptitiously metaphorical and non-conceptual and holds within it what he calls a "surplus value". This surplus value is most evident in the metaphysical language that is driven to "concepts in the negative" such as "ab-solute, in-finite, non-Being" (Derrida 1990, p. 121). These are also 
supposed to be real events in the absence of specificity, and metaphysical language is supposed to properly elucidate them. But if such language truly pointed to negative events, one could argue that, properly speaking, it would not be elucidatory.

2 This was partially the subject of the Introduction to my book, Merleau-Ponty between Philosophy and Symbolism: The Matrixed Ontology (Kaushik 2019, pp. xiv-xvii). I have subsequently written further about this in two articles: "The secondary passivity: Merleau-Ponty at the limit of phenomenology" (Kaushik 2021, pp. 61-74); “Where is Negation in Merleau-Ponty's Ontology? Symbolic Formation and the Implex" (Kaushik Forthcoming, pp. 372-93).

3 Here, I am re-asserting my theses from an earlier book, Art, Language and Figure in Merleau-Ponty: Excursions in Hyper-Dialectic (Kaushik 2013), in which drawing and writing are considered extensively (in the works of Paul Klee and Cy Twombly especially).

4 See again Merleau-Ponty Between Philosophy and Symbolism, especially in the "Some Remaining Questions" section at the end of Chapter Four (Kaushik 2019).

5 Blanchot would continue to invoke the limit experience of such a cry at a distance from the ideology of language in his The Infinite Conversation (Blanchot 1993, p. 262).

6 I am borrowing here from Merleau-Ponty's description of Freudian psychoanalysis in "Man and Adversity", found in Signs (Merleau-Ponty 1964, p. 229).

7 The reference in its entirety reads: The description of the oneiric structure (impossibility of expressing, dictatorship of figuration, condensation as sole means of expression) would attribute the disguise of latent thoughts as much to the condition of the dream as to [the] censor-repressed struggle-Consequently, latent content not to be represented as thought in the depth of ourselves in the mode of conventional thought, as an absolute observer would represent it. The unconsciousness of the unconscious [is the] unknown; but not known by someone in the depth of ourselves. The unconscious [is the] abandonment of the norms of wakeful expression, i.e., of the symbolic as symbolic of self, direct language, which presupposes distance and participation in the category. But this unconscious is not distant; it is quite near, as ambivalence. The "affective content" is not even unconscious or repressed, i.e., the unconscious as pulsation of desire is not behind our back. [The] unconscious [is the] implex, [the] animal, not only of words, but of events, of symbolic emblems. [The] unconscious [is] unknown acting and organising dream and life, principle of crystallization (rameau de Salzbourg), not behind us, fully within our field, but pre-objective, like the principle of segregation of "things" (Merleau-Ponty 2010, pp. 158-59).

8 "Language in forming itself expresses, at least laterally, an ontogenesis of which it is a part. But from this it follows that the words most charged with philosophy are not necessarily those that contain what they say, but rather those that most energetically open upon being, because they more closely convey the life of the whole and make our habitual evidences vibrate until they disjoin. Hence it is a question whether philosophy as the re-conquest of brute or wild being can be accomplished by the resources of the eloquent language, or whether it would not be necessary for philosophy to use language in a way that takes from it its power of immediate or direct signification in order to equal it with what it wishes all the same to say" (Merleau-Ponty 1968, pp. 102-3)

9 Le Problème de la parole: cours au Collège de France, notes, 1953-1954 (Merleau-Ponty 2020). For a discussion of this text see: Anden, Lovisa. "Being in Language: Merleau-Ponty's Examinations of Philosophical Speech at the Collège de France Sur le problème de la parole 1954". Forthcoming in Chiasmi International Vol. 23. (Anden forthcoming)

10 " ... expression of the mute experience by itself, is creation. A creation that is at the same time a reintegration of Being: for it is not a creation in the sense of the commonplace Gebilde that history fabricates: it knows itself to be Gebilde and wishes to surpass itself as pure Gebilde, to find again its origin. it is hence a creation in a radical sense: a creation that is at the same time an adequation, the only way to obtain an adequation. This considerably deepens Souriau's views on philosophy as supreme art: for art and philosophy together are precisely not arbitrary fabrications in the universe of the "spiritual" (of "culture"), but contact with Being precisely as creations. Being is what requires creation of us for us to experience it. Make an analysis of literature in this sense: as inscription of Being ..." (Merleau-Ponty 1968, pp. 247-48).

11 In "A Note on the Relation between Étienne Souriau's L'instauration philosophique and Deleuze and Guattari's What is Philosophy?" Leonard Lawlor writes: "In instauration and creation, the repetition is necessary. Yet, in instauration, the necessity arises not only because nothing can be produced without using previous traits, functions, and features. The necessity also arises because the instauration was not possible the first time. It is this "not possible" or this "what had not been able to be" that distinguishes instauration from creation in Deleuze and Guattari. In What is Philosophy?, Deleuze and Guattari think that concepts have been and can be created; creation is possible; it can be achieved. To lay out a plane of immanence without any transcendence whatsoever, that is impossible" (Lawlor 2011, pp. 400-6).

\section{References}

Anden, Lovisa. forthcoming. Being in Language: Merleau-Ponty's Examinations of Philosophical Speech at the Collège de France Sur le problème de la parole 1954. Chiasmi International: 23.

Barbaras, Renaud. 2004. The Being of the Phenomenon: Merleau-Ponty's Ontology. Bloomington: Indiana University Press.

Barbaras, Renaud. 2009. Le Tournant de l'experience. France: Librarie Philosophique J. Vrin.

Blanchot, Maurice. 1993. The Infinite Conversation. Translated by Susan Hanson. Minneapolis: University of Minnesota Press.

De Saint Aubert, Emmanuel. 2020. Merleau-Ponty's Poets and Poetics, with Mauro Carbone and Galen Johnson. New York: Fordham University Press. 
De Saussure, Ferdinand. 2009. Course in General Linguistics. Translated by Roy Harris. Peru: Open Court.

Derrida, Jacques. 1982. Margins of Philosophy. Translated by Alan Bass. Chicago: University of Chicago Press.

Derrida, Jacques. 1990. White Mythologies: Writing History and the West. Translated by Robert J.C. Young. London: Routledge.

Derrida, Jacques. 2005. On Touching_Jean-Luc Nancy. Translated by Christine Irizarry. Palo Alto: Stanford University Press.

Derrida, Jacques. 2010. Voice and Phenomena: Introduction to the Problem of Signs in Husserl's Phenomenology. Translated by Leonard Lawlor. Evanston: Northwestern University Press.

Freud, Sigmund. 1992. "Revision of the Theory of Dreams" in Essential Papers on Dreams. Edited by Melvin R. Lansky. New York: New York University Press.

Gendlin, Eugene. 1997. Experiencing and the Creation of Meaning: A Philosophical and Psychological Approach to the Subjective. Evanston: Northwestern University Press.

Kaushik, Rajiv. 2013. Art, Language and Figure in Merleau-Ponty: Excursions in Hyper-Dialectic. New York: Bloomsbury Academic.

Kaushik, Rajiv. 2019. Merleau-Ponty between Philosophy and Symbolism: The Matrixed Ontology. New York: State University of New York Press.

Kaushik, Rajiv. 2021. The secondary passivity: Merleau-Ponty at the limit of phenomenology. Continental Philosophy Review 54: 61-74. [CrossRef]

Kaushik, Rajiv. Forthcoming. Where is Negation in Merleau-Ponty's Ontology? Symbolic Formation and the Implex. Reaseach in Phenomenology: 372-93.

Lawlor, Leonard. 2011. A Note on the Relation between Étienne Souriau's L'instauration philosophique and Deleuze and Guattari's What is Philosophy? Deleuze Studies 5: 400-6. [CrossRef]

Mazis, Glen. 2016. Merleau-Ponty and the Face of the World: Silence, Ethics, Imagination, and Poetic Ontology. Albany: State University of New York Press.

Merleau-Ponty, Maurice. 1964. Signs. Translated by Richard C. Mcleary. Evanston: Northwestern University Press.

Merleau-Ponty, Maurice. 1968. The Visible and the Invisible. Translated by Alphonso Lingis. Evanston: Northwestern University Press.

Merleau-Ponty, Maurice. 2010. Institution and Passivity: Course Notes from the Collège de France (1954-1955). Translated by Leonard Lawlor, and Heath Massey. Evanston: Northwestern University Press.

Merleau-Ponty, Maurice. 2013. Recherches sur l'usage Littéraire du Langage: Cours au Collège de France Notes. Switzerland: MētisPresses. First published in 1953.

Merleau-Ponty, Maurice. 2019. A Theory and a Concordant Practice of Language. Translated by Rajiv Kaushik. Chiasmi International 21: 45-51. [CrossRef]

Merleau-Ponty, Maurice. 2020. Le Problème de la parole: Cours au Collège de France, Notes, 1953-1954. Paris: MētisPresses.

Souriau, Etienne. 1939. L'instauration Philosophique. Paris: Alcan. 